\title{
Three Simple and Economic Spectrophotometric Methods for Simultaneous Determination of Chitosan and Ascorbic Acid
}

\author{
Nourhan KH. Al-Afify ", Yossra A. Trabik, Nancy Magdy, Amira M. El-Kosasy \\ Department of Pharmaceutical Analytical Chemistry, Faculty of Pharmacy, Ain shams University, Cairo 11566, \\ Egypt
}

\begin{abstract}
Three simple, precise, and sensitive UV spectrophotometric methods have been developed and validated for the determination of Chitosan $(\mathrm{CH})$ in the presence of Ascorbic acid (AA) in a binary mixture. Method A is a derivative ratio method ( $\left.{ }^{1} \mathrm{DD}\right)$ that measures the peak amplitude of the first derivative for $\mathrm{CH}$ and $\mathrm{AA}$ at 207.2 and $282 \mathrm{~nm}$; respectively. Method $\mathrm{B}$ is a ratio difference method (RDSM) that measures the peak amplitude difference of the ratio spectra $\left(\Delta \mathrm{P}_{204.6-202.9}\right)$ and $\left(\Delta \mathrm{P}_{268-230}\right)$ for $\mathrm{CH}$ and $\mathrm{AA}$; respectively. Method $\mathrm{C}$ is a mean centering of ratio spectra method (MCR) that measures $\mathrm{CH}$ and $\mathrm{AA}$ at 204.6 and $269.1 \mathrm{~nm}$; respectively. Method A, B, and C were able to successfully determine the studied drugs in a concentration range of $0.5-9 \mu \mathrm{g} / \mathrm{mL}$ for $\mathrm{CH}$ and $2-20 \mu \mathrm{g} / \mathrm{mL}$ for AA. All results were statistically compared with the reported methods, where no significant difference was observed. The proposed methods were applied to the analysis of the studied drugs in pure and pharmaceutical formulations.
\end{abstract}

Keywords: Chitosan; Functional polymers; Spectrophotometry; Derivative ratio method $\left({ }^{1} D D\right) ;$ Ratio difference method (RDSM); Mean centering of ratio spectra method (MCR).

*Correspondence | Nourhan Al-Afify; Department of Pharmaceutical Analytical Chemistry, Faculty of Pharmacy, Ain shams University, Cairo 11566, Egypt. Email:: nourhan.alafify@ pharma.asu.edu.eg

Citation | Al-Afify NKH, Trabik YA, Magdy N, El-Kosasy AM, 2020. Three simple and economic spectrophotometric methods for simultaneous determination of Chitosan and Ascorbic acid. Arch Pharm Sci ASU 4(1): 92-103

DOI: $10.21608 /$ APS.2020.2004.1031

Print ISSN: 2356-8380. Online ISSN: 2356-8399.

Received 15 April 2020. Accepted 31 May 2020.

Copyright: ${ }^{\oplus} 2020$ Al-Afify et al. This is an open-access article licensed under a Creative Commons Attribution 4.0 International License (CC BY 4.0), which permits unrestricted use, distribution, and reproduction in any medium, provided the original author(s) and source are credited.

Published by: Ain Shams University, Faculty of Pharmacy

\section{INTRODUCTION}

Chitosan, is a naturally occurring polymer formed by partial deacetylation of chitin [1]. chitosan consists of $\beta(1,4)$ linked 2-acetamido-2deoxy- $\beta$-D-glucose ( $\mathrm{N}$ - acetylglucosamine) [2] (Fig. 1a). Chitosan is used in the treatment of wounds by accelerating their healing as the positive charge of chitosan halts bleeding by binding to negatively charged red blood cells resulting in fast coagulation [3]. Also, it enhances the hyaluronic acid synthesis and prevents scar formation [4].

$\mathrm{CH}$ is used as an antibacterial against oral bacteria as the negatively charged surface of bacteria interacts with the positively-charged amino groups, $\mathrm{NH}_{3}$, of $\mathrm{CH}$, and causes damage to the cell wall of the bacteria. Also, it is used as antifungal in toothpaste as it prevents the formation of plaque and tooth decay [5]. As well as, using $\mathrm{CH}$ in the form of nanoparticles 
improves its antimicrobial activity [1]. As well as, $\mathrm{CH}$ accelerates bone formation by increasing osteoblasts formations in bone tissues [6].

As well as, $\mathrm{CH}$ is also used as a bio-fertilizer, it has a positive charge so it can be used as a chelating agent for nutrient elements and enhances plant nutrient uptake efficiency so it enhances plant growth [7]. Also, $\mathrm{CH}$ improves water retention of the soil [8].

The literature review revealed that chitosan

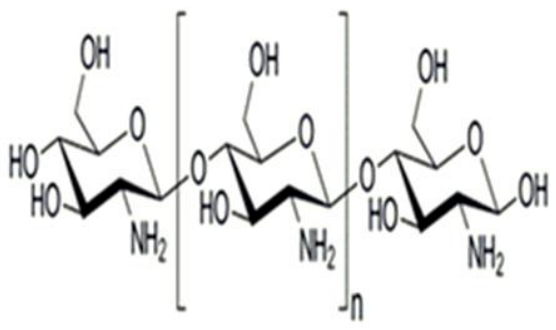

(a)

Fig. 1a. Structure of Chitosan

Literature review reported that ascorbic acid can be analyzed by spectrophotometry [21,22], HPLC [23-25], Fluorimetry [26,27] and potentiometry $[\mathbf{2 8 , 2 9 ]}$.

The literature showed that no methods were reported for the simultaneous analysis of $\mathrm{CH}$ and AA.

$\mathrm{CH}$ plays an important role in weight loss by preventing the absorption of fats, while AA improves $\mathrm{CH}$ mixing with fats so it is important to analyze them together.

Our study aims to introduce new simple spectrophotometric methods for the determination of the investigated drugs in pure and pharmaceutical dosage formulations. can be analyzed by colorimetry [9-12], chromatography [13-17], and capillary electrophoresis $[18,19]$.

Ascorbic acid, (5R)-[(1S)-1,2Dihydroxyethyl]-3,4-dihydroxyfuran-2(5H)-one, (Fig. 1b) is a water-soluble vitamin found in some food. It acts as an antioxidant, protecting cells from the damage caused by free radicals. Also, it plays an important role in the formation of collagen in teeth, bones, connective tissue, and capillaries [20].

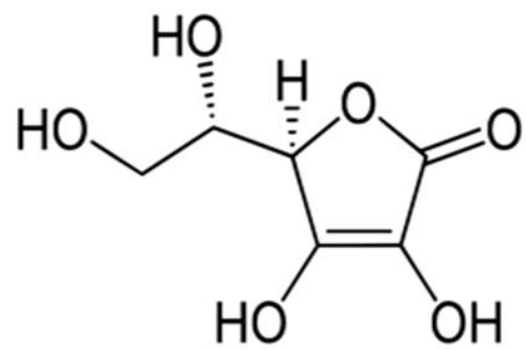

(b)

Fig. 1b. Structure of Ascorbic acid

\section{Experimental}

\subsection{Instrumentation}

SHIMADZU Dual-beam (Kyoto/Japan) UVVisible spectrophotometer model UV-1601 PC with $1 \mathrm{~cm}$ quartz cuvettes connected to IBM compatible computer fitted with UV-PC personal spectroscopy software version 3.7

Data analysis in the case of the MCR method was performed using Minitab® version 14.12.0 software.

$\mathrm{pH}$ meter $3510 \mathrm{pH} / \mathrm{mV} /{ }^{\circ} \mathrm{C}$ meter (Jenway, UK) with a combined glass electrode was used for $\mathrm{pH}$ adjustments.

\subsection{Chemicals and reagents}

\subsubsection{Pure samples}

AA was kindly supplied by Egyptian 
International Pharmaceutical Industries Company (EIPICO), Egypt and certified to be $100 \%$ while High Mwt CH (600,000-800,000 dalton) was purchased from Acros Organics ( USA) and certified to be $\geq 98 \%$

\subsubsection{Pharmaceutical formulations}

Chitocal@ capsules, labeled to contain $500 \mathrm{mg}$ $\mathrm{CH}, 100 \mathrm{mg} \mathrm{AA}$, and $50 \mathrm{mg}$ Gymnema Sylvestre Batch no. (172901), was manufactured by Debeiky Pharmaceuticals, Egypt.

\subsection{Reagents and solvents}

All chemicals and reagents used were of analytical grade. Bi-distilled water was used throughout the whole work and indicated by the word "Water". Phosphate buffer solution pH 8 was prepared by using potassium dihydrogen phosphate and disodium hydrogen phosphate (ADWIC, Egypt) with appropriate concentrations (0.1 M potassium dihydrogen phosphate was prepared by dissolving $13.61 \mathrm{~g}$ in $1 \mathrm{~L}$ and $0.1 \mathrm{M}$ disodium hydrogen phosphate was prepared by dissolving $17.8 \mathrm{~g}$ in $1 \mathrm{~L}$, then mixing $25 \mathrm{~mL}$ from $0.1 \mathrm{M}$ potassium dihydrogen phosphate solution with $475 \mathrm{~mL}$ from $0.1 \mathrm{M}$ disodium hydrogen phosphate solution to prepare $500 \mathrm{~mL}$ of phosphate buffer solution $\mathrm{pH} 8$ ). $1 \% \mathrm{v} / \mathrm{v}$ acetic acid was prepared by using water and acetic acid (ADWIC, Egypt)

\subsection{Standard solutions}

The standard stock solution of AA, (100 $\mu \mathrm{g} / \mathrm{mL}$ ) was prepared in water. $\mathrm{CH}$ standard stock solution $(100 \mu \mathrm{g} / \mathrm{mL})$ was prepared in $1 \%$ $\mathrm{v} / \mathrm{v}$ acetic acid. These solutions were also used as working standard solutions and diluted with phosphate buffer $\mathrm{pH} 8$ to prepare serial dilutions.

\subsection{Procedures}

\subsubsection{Chitosan binary mixture}

Aliquots of standard working solutions of $\mathrm{CH}$ and $\mathrm{AA}$ were diluted with phosphate buffer $\mathrm{pH} 8$ to prepare a concentration of $5 \mu \mathrm{g} / \mathrm{mL}$. Each was separately scanned over the range $200-400 \mathrm{~nm}$ using phosphate buffer $\mathrm{pH} 8$ as a blank

\subsection{2. ${ }^{1} \mathrm{DD}$}

The stored spectra of $\mathrm{CH}$ were divided by the spectrum of $4 \mu \mathrm{g} / \mathrm{mL}$ of $\mathrm{AA}$ while the stored spectra of AA were divided by the spectrum of 5 $\mu \mathrm{g} / \mathrm{mL}$ of $\mathrm{CH}$, then the amplitude of the first derivative of the ratio spectra was recorded at $207.2 \mathrm{~nm}$ for $\mathrm{CH}$ and $282 \mathrm{~nm}$ for AA (scaling factor $=1$ and $\Delta \lambda=4$ ). The peak amplitudes were plotted versus the corresponding concentration of $\mathrm{CH}$ and AA $(0.5-9 \mu \mathrm{g} / \mathrm{mL}$ and 2-20 $\mu \mathrm{g} / \mathrm{mL}$; respectively) and the regression equations were computed.

\subsubsection{RDSM}

The stored spectra of $\mathrm{CH}$ were divided by the spectrum of $4 \mu \mathrm{g} / \mathrm{mL}$ of AA while the stored spectra of AA were divided by the spectrum of 5 $\mu \mathrm{g} / \mathrm{mL}$ of $\mathrm{CH}$, then the amplitude differences of the ratio spectra $\left(\Delta \mathrm{P}_{204.6-202.9}\right)$ for $\mathrm{CH}$ and $\left(\Delta \mathrm{P}_{268-}\right.$ 230) for AA, were plotted versus the corresponding concentrations of $\mathrm{CH}$ and AA $(0.5-9 \mu \mathrm{g} / \mathrm{mL}$ and $2-20 \mu \mathrm{g} / \mathrm{ml}$; respectively) and the regression equations were computed.

\subsubsection{MCR}

The stored spectra of $\mathrm{CH}$ were divided by the spectrum of $4 \mu \mathrm{g} / \mathrm{mL}$ of AA while the stored spectra of AA were divided by the spectrum of 5 $\mu \mathrm{g} / \mathrm{mL} \mathrm{CH}$, to obtain the ratio spectra which were then mean-centered and measured at $204.6 \mathrm{~nm}$ and $269.1 \mathrm{~nm}$; respectively then plotted against the corresponding concentrations of $\mathrm{CH}$ and $\mathrm{AA}$ (0.5-9 $\mu \mathrm{g} / \mathrm{mL}$ and $2-20 \mu \mathrm{g} / \mathrm{mL}$; respectively). The regression equations were computed.

\subsection{Application on laboratory prepared mixtures}

Several laboratory prepared mixtures of varying ratios of $\mathrm{CH}$ and $\mathrm{AA}$ were prepared and 
the corresponding concentrations were determined by the previously mentioned methods.

\subsection{Application on pharmaceutical formulations}

\section{Chitocal ${ }^{\circledR}$ capsule}

Twenty capsules of Chitocal ${ }^{\circledR}$ were emptied and weighed. An accurately weighed amount of the fine powder equivalent to $469.704 \mathrm{~g} \mathrm{CH}$ and $93.94 \mathrm{~g}$ AA was weighed and transferred accurately into $100 \mathrm{~mL}$ volumetric flask and completed to the mark with $1 \%$ acetic acid to prepare $4697.04 \mu \mathrm{g} / \mathrm{mL} \mathrm{CH}$ and $939.4 \mu \mathrm{g} / \mathrm{mL}$ AA stock solutions. Then a suitable dilution with phosphate buffer $\mathrm{pH} 8$ was made from the prepared stocks to obtain $4 \mu \mathrm{g} / \mathrm{ml}$ AA sample and $3 \mu \mathrm{g} / \mathrm{mL}$ CH sample.

The above-mentioned procedures were followed. To check the validity of the proposed methods, the standard addition technique was adopted.

\section{RESULTS AND DISCUSSION}

Three simple and economic spectrophotometric methods were developed for rapid analysis of $\mathrm{CH}$ and $\mathrm{AA}$ in their binary mixtures, as well as in multi-ingredients formulations (e.g. weight loss formulations), as the amino groups of $\mathrm{CH}$ bind to negatively

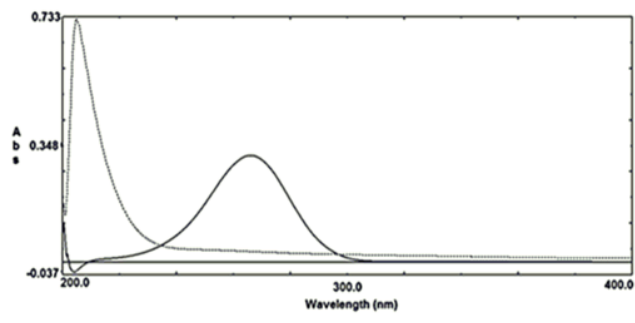

charged molecules like lipids and prevent their absorption and storage by the body [30]. AA reduces the viscosity of $\mathrm{CH}$ and improves its ability to mix with the fat in the GIT [31], That is why it was essential to analyze them together in their formulations.

Since the traditional derivative technique failed to resolve the severely overlapped spectra of the studied drugs as in (Fig. 2a and Fig. 2b), so it was crucial to develop new methods able to selectively analyze each of the studied drugs.

Analysis of $\mathrm{CH}$ by UV spectrophotometry methods was challenging as it lacks conjugation and did not have significant peaks in the middle and near UV regions, so the proposed methods were the first UV spectrophotometric methods for the analysis of $\mathrm{CH}$ in pure and pharmaceutical formulations.

Many solvents and buffered solutions were tried to shift $\mathrm{CH}$ wavelength to a longer one. Phosphate buffer $\mathrm{pH} 8$ was the solvent of choice as it made a bathochromic shift to $\mathrm{CH}$-spectrum and allowed it to be measured in the UV region. The reason is that the $\mathrm{CH}$ amino group becomes protonated when dissolved in $1 \%$ acetic acid and then when phosphate buffer $\mathrm{pH} 8$ is used as a solvent for the preparation of serial dilutions, the protonated amino group becomes free again and regains its lone pair, which leads to bathochromic shift.

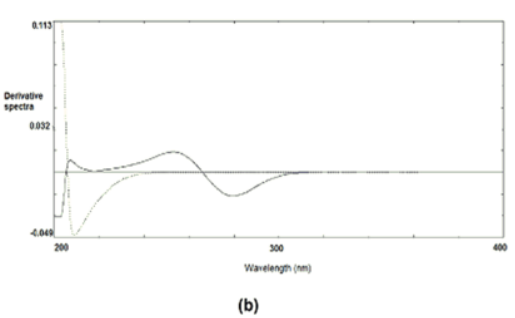

Fig. 2a. Zero order absorption spectra of $\mathrm{CH}$ and $\mathrm{AA} 5 \mu \mathrm{g} / \mathrm{mL}$, each using Phosphate buffer PH 8 as a blank

Fig. 2b. First derivative spectra $\mathrm{CH}$ and AA $5 \mu \mathrm{g} / \mathrm{mL}$, each using Phosphate buffer PH 8 as a blank

(dashes for $(\mathrm{CH})$ and solid line for $(\mathrm{AA})$ ) 


\subsection{Chitosan binary mixture}

\subsection{1. ${ }^{1} \mathrm{DD}$}

This method is done by division of the mixture's spectrum by the spectrum of a fixed component named "divisor" then the derivative ratio spectra were recorded [32].

The stored spectra of $\mathrm{CH}$ were divided by the spectrum of $4 \mu \mathrm{g} / \mathrm{mL}$ of AA then the amplitude of the first derivative of the ratio spectra was recorded at $207.2 \mathrm{~nm}$ (Fig. 3a).

While the stored spectra of AA were divided by the spectrum of $5 \mu \mathrm{g} / \mathrm{mL}$ of $\mathrm{CH}$, then the amplitude of the first derivative of the ratio spectra was recorded at $282 \mathrm{~nm}$ (Fig. 3b).

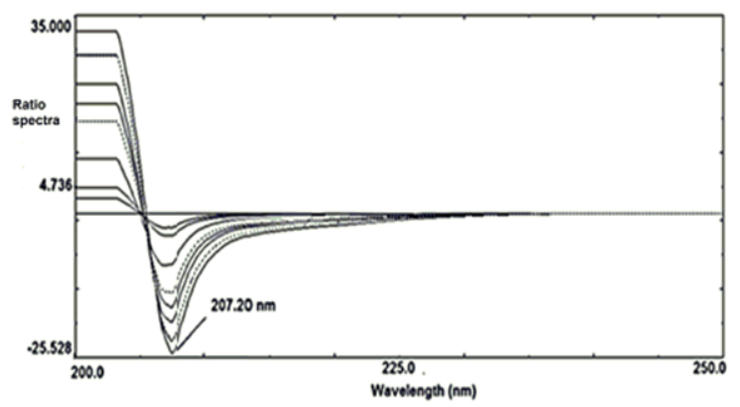

(a)
This method was optimized by testing the influence of many variables such as

The wavelength increment over which the derivative was obtained $(\Delta \lambda)$. It was found that $\Delta \lambda=4$ and scaling factor $=1$ gave the best results in terms of signal to noise ratio, peak resolution, and sensitivity throughout the determination. The effect of divisor concentration was tested, and it was found that $4 \mu \mathrm{g} / \mathrm{mL}$ AA and $5 \mu \mathrm{g} / \mathrm{mL} \mathrm{CH}$ as a divisor for determination of $\mathrm{CH}$ and $\mathrm{AA}$; respectively were the best in case of sensitivity and response.

Fig. 3a. First derivative of ratio spectra of $\mathrm{CH}(0.50-9.00 \mu \mathrm{g} / \mathrm{mL})$ at $207.20 \mathrm{~nm}$ using $4 \mu \mathrm{g} / \mathrm{mL}$ of AA as a divisor and phosphate buffer $\mathrm{pH} 8$ as blank

Fig. 3b. First derivative of ratio spectra of AA $(2.00-20.00 \mu \mathrm{g} / \mathrm{mL})$ at $282.00 \mathrm{~nm}$ using $5 \mu \mathrm{g} / \mathrm{mL}$ of CH as a divisor and phosphate buffer $\mathrm{pH} 8$ as a blank

\subsubsection{RDSM}

This method is based on the amplitude difference between two points on the ratio spectra of a mixture, which is directly proportional to the concentration of the component of interest $[33,34]$.

The stored spectra of $\mathrm{CH}$ were divided by the spectrum of $4 \mu \mathrm{g} / \mathrm{mL}$ of AA then the amplitude difference of the ratio spectra $\left(\Delta \mathrm{P}_{204.6-202.9}\right)$ was computed (Fig. 4a). While the stored spectra of

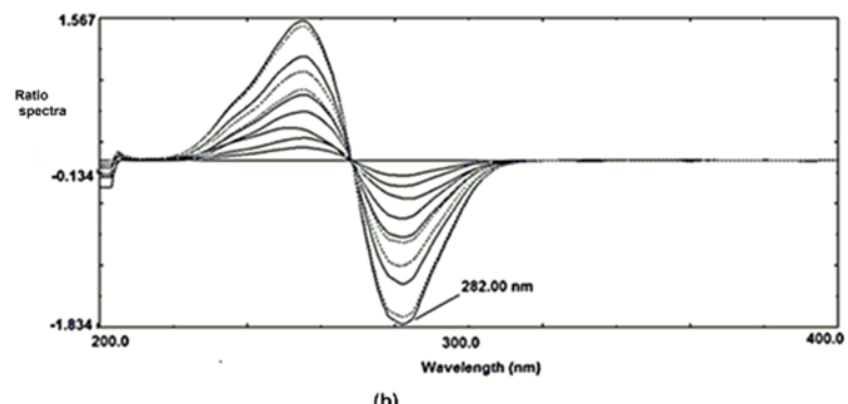

(b) 
exhibited difference amplitudes in ratio spectrum and good linearity is present at each wavelength individually.

\subsubsection{MCR}

The proposed MCR method is based on the mean centering of the ratio spectra. It eliminates the derivative steps, therefore it enhances the signal to noise ratio. It has been applied for resolving binary and ternary mixtures in complex samples with unknown matrices [35]. The mathematical explanation of the developed method was illustrated by Afkhami and Bahram [36].

After method optimization, $\mathrm{CH}$ and AA have been successfully determined at $204.6 \mathrm{~nm}$ and $269.1 \mathrm{~nm}$; respectively as shown in (Fig. 5a) and (Fig. 5b).

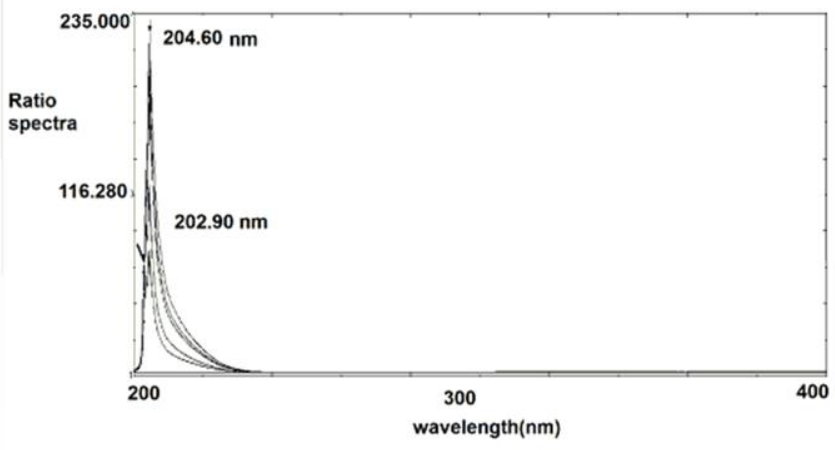

(a)

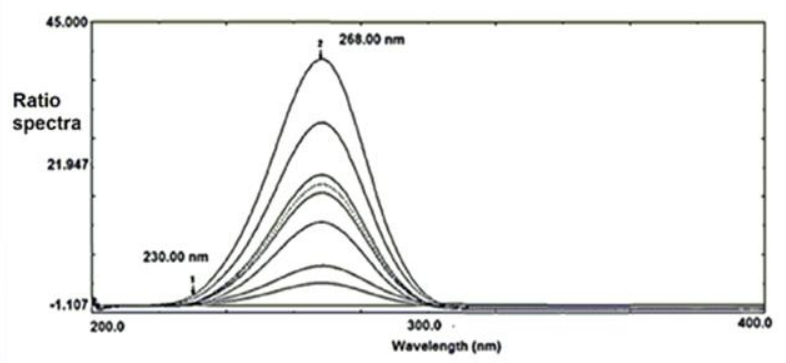

(b)

Fig. 4a. Ratio spectra of $(2.5,4.5,7.5,8$ and $9 \mu \mathrm{g} / \mathrm{mL})$ of $\mathrm{CH}$ showing the selected wavelengths $(202.9 \mathrm{~nm}$ and $204.6 \mathrm{~nm})$ for ratio difference method using phosphate buffer $\mathrm{pH} 8$ as blank

Fig. 4b. Ratio spectra of AA showing the selected wavelengths ( $230 \mathrm{~nm}$ and $268 \mathrm{~nm}$ ) for ratio difference method using phosphate buffer $\mathrm{pH} 8$ as a blank

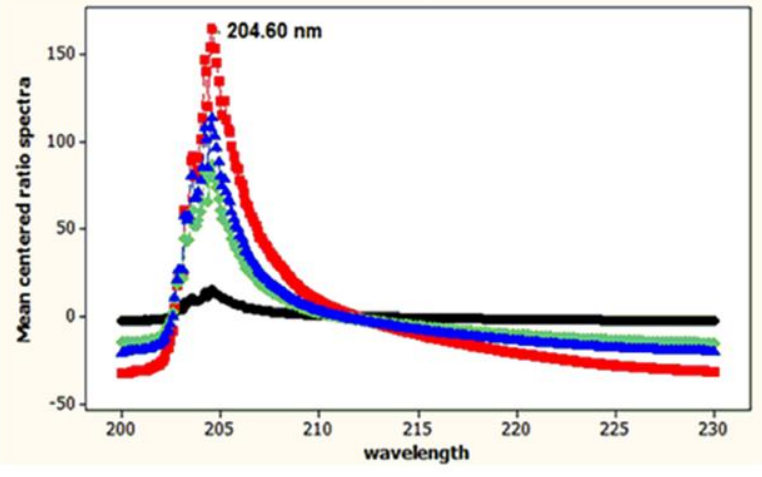

(a)

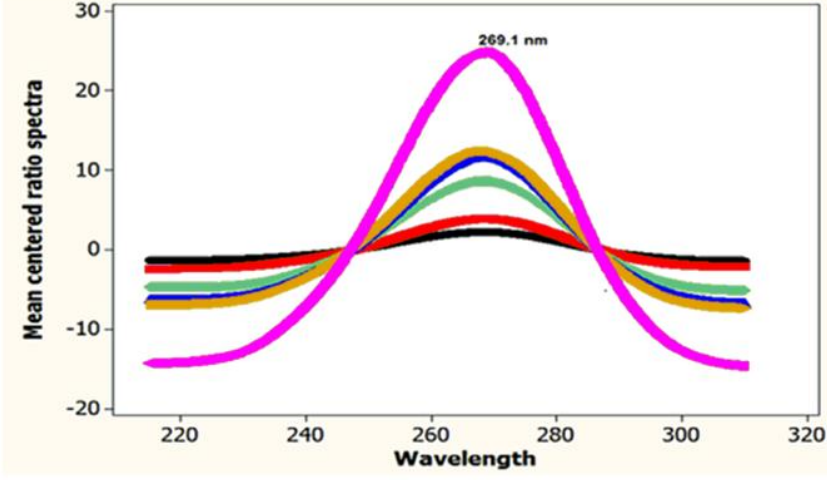

(b)

Fig. 5a. The mean centered of ratio absorption spectra of $(0.50,4.00,5.50,8.00 \mu \mathrm{g} / \mathrm{mL}) \mathrm{CH}$ in phosphate buffer $\mathrm{pH} 8$ at 204.60 $\mathrm{nm}$

Fig. 5b. The mean centered of ratio absorption spectra of $(2.00,3.00,7.00,10.00,15.00,20.00 \mu \mathrm{g} / \mathrm{mL})$ AA in phosphate buffer $\mathrm{pH} 8$ at $269.10 \mathrm{~nm}$ 
Table 1. Calibration data for the determination of $\mathrm{CH}$ and $\mathrm{AA}$ by the proposed methods

\begin{tabular}{|c|c|c|c|c|c|c|c|c|c|c|}
\hline Methods & Drugs & $\begin{array}{l}\text { Working } \\
\lambda(\mathrm{nm})\end{array}$ & $\begin{array}{l}\text { Range } \\
(\mu \mathrm{g} / \mathrm{mL})\end{array}$ & $\begin{array}{l}\text { Regression } \\
\text { equation }\end{array}$ & $\mathbf{r}$ & $\begin{array}{l}\text { LOD } \\
(\mu \mathrm{g} / \mathrm{mL})\end{array}$ & $\begin{array}{l}\text { LOQ } \\
(\mu \mathrm{g} / \mathrm{mL})\end{array}$ & $\begin{array}{l}\text { Accuracy } \\
\pm \text { SD }\end{array}$ & $\begin{array}{l}\text { Intraday } \\
\text { RSD\% }\end{array}$ & $\begin{array}{c}\text { Interday } \\
\text { RSD\% }\end{array}$ \\
\hline \multirow{2}{*}{${ }^{1} \mathrm{DD}$} & Chitosan & 207.20 & $\begin{array}{l}0.50- \\
9.00\end{array}$ & $Y=2.4811 C+1.4575$ & 0.9998 & 0.15 & 0.45 & $\begin{array}{l}100.78 \pm \\
1.29\end{array}$ & 0.95 & 1.26 \\
\hline & $\begin{array}{l}\text { Ascorbic } \\
\text { acid }\end{array}$ & 282.00 & $\begin{array}{l}2.00- \\
20.00\end{array}$ & $\mathrm{Y}=0.0901 \mathrm{C}+0.0010$ & 0.9998 & 0.44 & 1.33 & $\begin{array}{l}100.11 \pm \\
1.15\end{array}$ & 1.28 & 1.95 \\
\hline \multirow{2}{*}{ RDSM } & Chitosan & $\begin{array}{c}204.60 \\
\text { and } \\
202.90\end{array}$ & $\begin{array}{l}0.50- \\
9.00\end{array}$ & $Y=17.3015 C+4.0719$ & 0.9999 & 0.12 & 0.3 & $\begin{array}{c}99.21 \pm \\
0.95\end{array}$ & 1.26 & 1.95 \\
\hline & $\begin{array}{l}\text { Ascorbic } \\
\text { acid }\end{array}$ & $\begin{array}{c}268.00 \\
\text { and } \\
230.00\end{array}$ & $\begin{array}{l}2.00- \\
20.00\end{array}$ & $Y=1.8659 \mathrm{C}+0.0006$ & 0.9997 & 0.49 & 1.49 & $\begin{array}{c}100.54 \pm \\
0.86\end{array}$ & 1.21 & 1.95 \\
\hline \multirow[t]{2}{*}{ MCR } & Chitosan & 204.60 & $\begin{array}{l}0.50- \\
9.00\end{array}$ & $Y=19.4473 C+8.2451$ & 0.9999 & 0.13 & 0.39 & $\begin{array}{c}99.48 \pm \\
1.41\end{array}$ & 1.46 & 1.45 \\
\hline & $\begin{array}{l}\text { Ascorbic } \\
\text { acid }\end{array}$ & 269.10 & $\begin{array}{l}2.00- \\
20.00\end{array}$ & $Y=1.2437 \mathrm{C}-0.0037$ & 0.9997 & 0.39 & 1.18 & $\begin{array}{l}100.29 \pm \\
0.95\end{array}$ & 1.57 & 1.59 \\
\hline
\end{tabular}

r: correlation coefficient, LOD: Limit of detection, LOQ: Limit of quantitation, C: concentration of drugs in $\mu \mathrm{g} / \mathrm{mL}$

\subsection{Method validation}

\subsubsection{Linearity}

The linearity of the proposed methods was evaluated using different concentrations of standard solutions where all the methods show good correlation coefficients close to unity, indicating good linearity, as shown in Table 1.

\subsubsection{Accuracy}

The accuracy of the results was checked by applying the proposed methods for the determination of different samples of $\mathrm{CH}$ and AA. The concentrations were obtained from the corresponding regression equations, and the recoveries were calculated, as shown in Table $\mathbf{1}$.

\subsubsection{Precision}

Intraday and interday precision of three concentrations of $\mathrm{CH}(4,5,8 \mu \mathrm{g} / \mathrm{mL})$ by using ${ }^{1} \mathrm{DD},(3.5,4.5,7 \mu \mathrm{g} / \mathrm{mL})$ by using RDSM and ( 2.5,3,4 $\mu \mathrm{g} / \mathrm{mL}$ ) by using MCR, and for AA ( $13,18,19 \mu \mathrm{g} / \mathrm{mL}$ ) by using ${ }^{1} \mathrm{DD}, \mathrm{RDSM}$, and MCR were checked. The obtained results for the proposed methods showed accepted results due to low values of \% RSD as shown in Table 1.

\subsubsection{Limits of detection and quantitation}

The limit of detection (LOD) and limit of quantitation (LOQ) were calculated as $\mathrm{LOD}=3.3$ $(\sigma / \mathrm{S})$ and $\mathrm{LOQ}=10(\sigma / \mathrm{S})$, where ' $\sigma$ ' represents the standard deviation of the intercept and ' $S$ ' is the slope of the calibration curve as shown in Table 1. 


\subsubsection{Selectivity}

Selectivity was checked by analyzing of $\mathrm{CH}$ with AA in laboratory prepared mixtures with different ratios and was ensured by the results presented in Table 2.

Table 2. Selectivity results for determination of Chitosan and Ascorbic acid in laboratory prepared mixtures using the proposed methods

\begin{tabular}{|c|c|c|c|c|c|c|}
\hline \multicolumn{7}{|c|}{ *Recovery\% } \\
\hline \multicolumn{4}{|c|}{ Chitosan } & \multicolumn{3}{|c|}{ Ascorbic acid } \\
\hline Ratio of mixture components & ${ }^{1}$ DD & RDSM & MCR & ${ }^{1} \mathrm{DD}$ & RDSM & MCR \\
\hline \multicolumn{7}{|l|}{ (Chitosan : Ascorbic acid) } \\
\hline 1:1 & 98.56 & & & 100.67 & & \\
\hline 3:1 & 98.78 & & & 100.00 & & \\
\hline 3:4 & 98.33 & & & 98.17 & & \\
\hline $2.25: 3$ & 99.56 & 102.00 & & 99.83 & 101.67 & \\
\hline 2.83:1 & 99.41 & & & 100.67 & & \\
\hline $2.5: 3$ & & 99.20 & & & 99.33 & \\
\hline 3.75:1 & & 101.07 & & & 100.50 & \\
\hline $1.5: 2$ & & 98.27 & & & 99.80 & \\
\hline 2.75:1 & & 101.09 & & & 99.00 & \\
\hline $1.4: 2$ & & & 101.43 & & & 99.20 \\
\hline 3.5:1 & & & 100.43 & & & 102.00 \\
\hline 1:1.57 & & & 100.43 & & & 100.45 \\
\hline $0.7: 1$ & & & 100.86 & & & 99.40 \\
\hline 2.33:1 & & & 98.71 & & & 98.33 \\
\hline \multirow{2}{*}{ Mean \pm SD } & 98.93 & 100.33 & 100.37 & 99.87 & 100.06 & 99.88 \\
\hline & \pm 0.54 & \pm 1.54 & \pm 1.02 & \pm 1.02 & \pm 1.06 & \pm 1.41 \\
\hline
\end{tabular}

* Mean of three determinations

\subsection{Application to pharmaceutical formulations}

The proposed methods were successfully applied to pharmaceutical formulations and the standard addition technique was performed. The concentrations were calculated using the corresponding regression equations as shown in

\section{Table 3.}

\subsection{Statistical analysis}

A statistical comparison between the results obtained by the proposed methods and those of the reported methods $[\mathbf{1 0}, \mathbf{2 3}]$ of $\mathrm{CH}$ and $\mathrm{AA}$ was done. The difference between the proposed and reported methods were tested by F-test and t-test as shown in Table 4 . The test ascertained that there was no significant difference concerning accuracy and precision between the proposed methods and the reported methods $[\mathbf{1 0 , 2 3}]$.

\section{Conclusion}

The proposed spectrophotometric methods for the determination of $\mathrm{CH}$ and $\mathrm{AA}$ could be successfully applied. The results showed good selectivity, accuracy, and precision demonstrating that they are rapid, selective, sensitive, economic and reproducible. So, the proposed methods are of great value for routine 
efficient analysis of the cited drugs in its ease of use, and low costs over other analytical pharmaceutical formulations. Also, the proposed methods as shown in Table 5.

methods offer distinct advantages in simplicity,

Table 3. Application of the proposed methods for determination of $\mathrm{CH}$ and AA in pharmaceutical formulations

\begin{tabular}{|c|c|c|c|c|c|c|c|c|c|c|}
\hline \multirow{3}{*}{$\begin{array}{l}\text { pharmaceutical } \\
\text { Formulations } \\
\text { Marketed Chitocal }{ }^{\circ} \\
\text { capsule } \\
\text { Formulation labeled } \\
\text { to contain }\end{array}$} & \multirow[t]{3}{*}{ Drugs } & \multicolumn{3}{|c|}{${ }^{1} \mathrm{DD}$} & \multicolumn{3}{|c|}{ RDSM } & \multicolumn{3}{|c|}{ MCR } \\
\hline & & $\begin{array}{l}\text { Found*\% } \\
\pm \text { S.D }\end{array}$ & \multicolumn{2}{|c|}{ Standard addition } & $\begin{array}{l}\text { Found*,\% } \\
\pm \text { S.D }\end{array}$ & \multicolumn{2}{|c|}{ Standard addition } & $\begin{array}{l}\text { Found*,\% } \\
\pm \text { S.D }\end{array}$ & \multicolumn{2}{|c|}{ Standard addition } \\
\hline & & 101.00 & Added & Recovery \% & 101.33 & Added & Recovery \% & 100.11 & Added & Recovery \% \\
\hline $\begin{array}{l}500 \text { mg Chitosan,100 } \\
\text { mg Ascorbic acid }\end{array}$ & & \pm 0.33 & $(\mu \mathrm{g} / \mathrm{mL})$ & & \pm 0.34 & $(\mu \mathrm{g} / \mathrm{mL})$ & & \pm 0.19 & $(\mu \mathrm{g} / \mathrm{mL})$ & \\
\hline and $50 \mathrm{mg}$ & & & 2.00 & 100.50 & & 2.00 & 101.50 & & 2.00 & 99.00 \\
\hline \multicolumn{11}{|l|}{ Gymnema } \\
\hline & & & 3.00 & 99.00 & & 3.00 & 99.00 & & 3.00 & 99.33 \\
\hline \multicolumn{11}{|l|}{ Batch no. } \\
\hline \multirow{10}{*}{ ( 172901$)$} & & & $\operatorname{Mean} \pm$ & 100.42 & & Mean \pm & 100.08 & & Mean \pm SD & 98.78 \\
\hline & & & SD & \pm 1.38 & & SD & \pm 1.28 & & & \pm 0.69 \\
\hline & & 100.00 & Added & Recovery \% & 99.50 & Added & Recovery \% & 100.17 & Added & Recovery\% \\
\hline & & \pm 1.00 & $(\mu \mathrm{g} / \mathrm{mL})$ & & \pm 1.30 & $(\mu \mathrm{g} / \mathrm{mL})$ & & \pm 1.53 & $(\mu \mathrm{g} / \mathrm{mL})$ & \\
\hline & & & 2.00 & 98.50 & & 2.00 & 100.50 & & 2.00 & 100.50 \\
\hline & Ascorbic & & 4.00 & 101.25 & & 4.00 & 101.00 & & 4.00 & 101.50 \\
\hline & Acid & & & & & & & & & \\
\hline & & & 6.00 & 101.50 & & 6.00 & 100.50 & & 6.00 & 98.50 \\
\hline & & & $\operatorname{Mean} \pm$ SD & 101.42 & & Mean \pm SD & 100.50 & & Mean \pm SD & 100.17 \\
\hline & & & & \pm 1.66 & & & \pm 0.95 & & & \pm 1.53 \\
\hline
\end{tabular}

*Mean of three determinations

\section{Declarations}

\section{Ethics approval and consent to participate}

This study does not include any in vitro or in vivo studies (Not applicable).

\section{Consent to publish}

Not applicable

\section{Availability of data and materials}

All data generated or analyzed during this study are included in this published article in the main manuscript.

\section{Competing interests}

The authors declare that no competing interests exist

\section{Funding Statement}

This research did not receive any specific grant from funding agencies in the public, commercial, or not-for-profit sectors.

\section{Authors contributions}

The manuscript was drafted and written by Nourhan KH. Al-Afify. Yossra A. Trabik, Nancy Magdy, and Amira M.El-Kosasy have provided comments and contributed to revising the manuscript.

All authors have read and approved the final manuscript. 


\section{Acknowledgment}

The authors would like to acknowledge all colleagues in the Pharmaceutical analytical Chemistry Department, Ain Shams University for their support.

Table 4. Statistical comparison between the proposed spectrophotometric methods and the reported methods for $\mathrm{CH}$ and AA; respectively

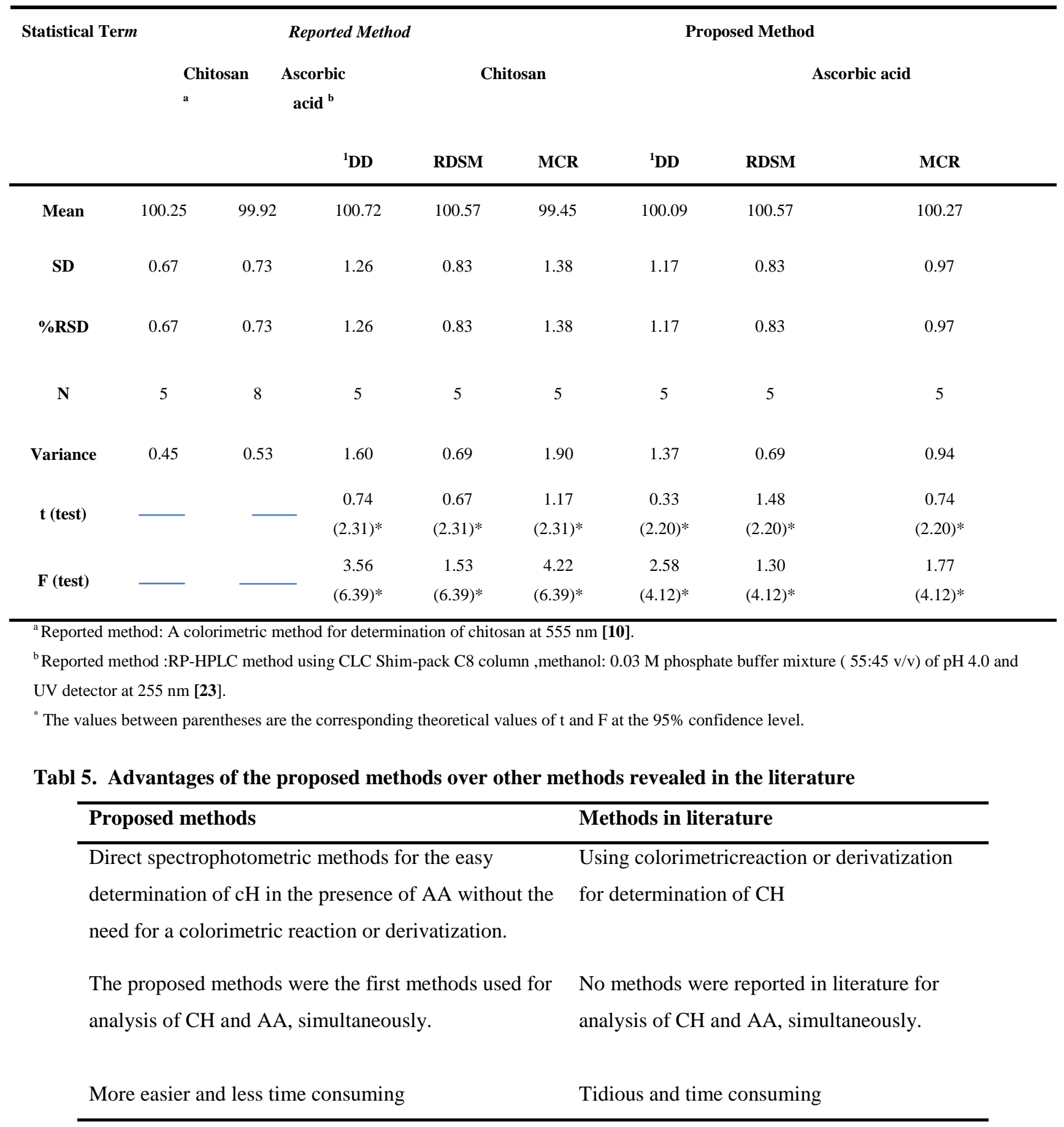




\section{REFERENCES}

1. Crisiane M., Virginia C. A. M., Ma H. L., Cristiane C. M., Dr. Ana M. G P., Rikke L. M. and Marcia.N., Combination of Rhamnolipid and Chitosan in Nanoparticles Boosts Their Antimicrobial Efficacy, ACS Appl. Mater. Interfaces. 12 (2020) 5488-5499. doi:10.1021/acsami.9b19253.

2. Mercy.H. P., Ahmad.S. H., Arman.Z.M. S., Chitosan: A promising marine polysaccharide for biomedical research, Pharmacogn. Rev. 10 (2016) 39-42. doi:10.4103/0973-7847.176545.

3. Vioria P., Vasile O., Gerrit B., Olivier J., Chitosan as a starting material for wound healing applications, Eur. J. Pharm. Biopharm. $97 \quad$ (2015) 417-426. https://doi.org/10.1016/j.ejpb.2015.08.004

4. Randy.C.F. C., Tzi.B. Ng, Jack.H. W., Wai.Y. C., Chitosan: An update on potential biomedical and pharmaceutical applications, 2015. doi: $10.3390 / \mathrm{md} 13085156$.

5. Kmiec M., Pighinelli L., Tedesco MF, Silva MM, Reis V, Chitosan-Properties and Applications in Dentistry, Adv. Tissue Eng. Regen. Med. 2 (2017) 205-211. doi:10.15406/atroa.2017.02.00035.

6. Begüm E.,Özkan A., Suzan C., Musa A., A General Overview of Chitosan and its Use in Dentistry, Inter. Bio. and Biomed. J. (IBBJ) 5 (2019) 1-11.

7. Rahat S., Muhammad M., Mati Ur R., Abdullah Sh., Husain A., Toheed A, Deng T.and Xiping W., The multifunctional role of chitosan in horticultural crops; a review, Molecules. 23, 872 (2018) 1-20.

8. Priyal P., Mahendra K. V., and Nirmal D., Chitosan in Agriculture Context- A Review, Bull. Environ. Pharmacol. Life Sci. 7,[5] (2018) 87-96

9. Nathalia.I. L., Dinara.K. Z., Dorel.T. G., M.A. Pechyonkin, Nadezda.G. B., Colorimetric assay of chitosan in the presence of proteins and polyelectrolytes by using o-phthalaldehyde, Carbohydr. Polym. 75 (2009) 724-727. doi:10.1016/j.carbpol.2008.10.009.

10. Mohamed.E.I. B. A New Rapid and Sensitive Spectrophotometric Method for Determination of a Biopolymer Chitosan, Int. J. Carbohydr. Chem. 2012 (2012) 1-7. doi:10.1155/2012/139328.

11. Mohamed. Abou-Sh., A Simple Colorimetric Method for the Evaluation of Chitosan, Am. J. Anal. Chem. 02 (2010) 91-94.

12. Abhik M., Anjani.K. U., Vishaka R., Lopamudra R., A simple and rapid colorimetric method for the estimation of chitosan produced by microbial degradation of chitin waste, J. Microbiol. Methods. 158 (2019) 66-70. doi:10.1016/j.mimet.2019.02.001.

13. Mette H.O., Kjell M.V., Bjørn E.Ch.,Marit W.A., Olav S., Preparative and analytical size-exclusion chromatography of chitosans, Carhohyhale Polym. 31 (1996) 253-261. https://doi.org/10.1016/S01448617(96)00096-3

14. Morten E., Monica F., L. Roed, Yngve S., Determination of chitosan in wood and water samples by acidic hydrolysis and liquid chromatography with online fluorescence derivatization, Carbohydr. Polym. 61 (2005) 29-38. DOI: 10.1016/j.carbpol.2005.02.006

15. Wu A., Bough W., Conrad E., Alden K. J., Determination of Molecular-Weight Distribution of Chitosan by High-Performance Liquid Chromatography, Chromatogr. J. 128 (1976) 87-99. DOI: 10.1016/s00219673(00)84034-0

16. Yasser.S. El-S., Ahmed.A. Bary, High-performance liquid chromatographic determination of neutraceuticals, glucosamine sulfate and chitosan, in raw materials and dosage forms, Anal. Chim. Acta. 462 (2002) 125-131. DOI: $10.1016 / \mathrm{S} 0003-2670(02) 00279-9$

17. Xun Y., Heidi.M. E., Chitosan analysis using acid hydrolysis and HPLC/UV, Carbohydr. Polym. 87 (2012) 1774-1778. DOI: 10.1016/j.carbpol.2011.09.091

18. Ban E., Choi O., Ryu J., Yoo Y., Capillary electrophoresis of high-molecular chitosan: The natural carbohydrate biopolymer, Electrophoresis. 22 (2001) 2217-2221. DOI: 10.1002/15222683(20017)22:11<2217::AID-ELPS2217>3.0.CO;2-R

19. Xiaofang F., Ling H., Maolin Z., Wei L., Huwei L., Analysis of natural carbohydrate biopolymer-high molecular chitosan and carboxymethyl chitosan by capillary zone electrophoresis, Carbohydr. Polym. 68 (2007)

$511-516$ https://doi.org/10.1016/j.carbpol.2006.11.001

20. Vitamin C Fact Sheet for Consumers, U.S. Natl. Institutes Heal. (2019) https://ods.od.nih.gov/factsheets/VitaminC-Consumer/.

21. Milton K. S., Mario A. F., Elias.A.G. Z., Flow systems with $\mathrm{MnO} 2$-coated open tubular reactors for spectrophotometric determination of ascorbic acid in pharmaceutical products, Anal. Lett. 49 (2016) 627-638. doi:10.1080/00032719.2014.979353.

22. Maria.A. M., Elena.I. M., Silica-titania xerogel doped with Mo, P-heteropoly compounds for solid phase 
spectrophotometric determination of ascorbic acid in fruit juices, pharmaceuticals, and synthetic urine, Chem. Cent. J. 11 (2017) 1-8. doi:10.1186/s13065-016-0233-5.

23. Mohamed. Sh. El-D., M. E., and Abdallah.M.Z. M, Development, and Validation of RP- HPLC Method for Simultaneous Determination of Ascorbic Acid and Salicylamide in their Binary Mixtures: Application to Combined Tablets, J. Chromatogr. Sep. Tech. 03 (2012) 1-7. http://dx.doi.org/10.4172/2157-7064.1000137

24. Tamer.Z. A., Simultaneous determination of rutin and ascorbic acid mixture in their pure forms and combined dosage form, Spectrochim. Acta - Part A Mol. Biomol. $\begin{array}{llll}\text { Spectrosc. } & 169 & \text { (2016) }\end{array}$ doi:10.1016/j.saa.2016.06.030.

25. FatmaT., Remziye G., Erdal D., Simultaneous determination of ascorbic acid and caffeine in commercial soft drinks using reversed-phase ultraperformance liquid chromatography, J. Food Drug Anal. $25 \quad$ (2017) 285-292. doi:10.1016/j.jfda.2016.09.004.

26. Wensheng L., Xiaoyan. Q., Chenfeng. Z., Yuanhao G., Changjje M., Jiming S., Helin N., A two-dimensional zinc ( II ) -abased metal-organic framework for fluorometric determination of ascorbic acid, chloramphenicol and ceftriaxone, 187 (2020). doi.org/10.1007/s00604-019-3979-3

27. Wanwan C., Yanyan W., Dandan Y., Jianxiu. Du, Fluorometric determination of ascorbic acid by exploiting its deactivating effect on the oxidase-mimetic properties of cobalt oxyhydroxide nanosheets, Microchim. Acta. $184 \quad$ (2017) 4749-4755. doi:10.1007/s00604-017-2525-4.

28. Fariba T., Saba V., Hasan B., Au-Pd/reduced graphene oxide composite as a new sensing layer for electrochemical determination of ascorbic acid, acetaminophen and tyrosine, Mater. Sci. Eng. C. 68 (2016) 805-813. doi:10.1016/j.msec.2016.07.039.

29. Masoud T., Roman I., Sergei B., Sayed H. K., Irian Hussainova, Graphene-ceramic hybrid nanofibers for ultrasensitive electrochemical determination of ascorbic acid, Microchim. Acta. 184 (2017) 897-905. doi:10.1007/s00604-017-2085-7.

30. RitvaY., Saara L., Erkki W., Pauli Y., Terho L., Cholesterol-lowering properties and safety of chitosan, Arzneimittel-Forschung/Drug Res. 52 (2002) 1-7. doi:10.1055/s-0031-1299848.

31. Osamu K., Keiji D., Youji I., Eiichi K., Increasing Effect of a Chitosan and Ascorbic Acid Mixture on
Fecal Dietary Fat Excretion, Biosci. Biotechnol. Biochem. $58 \quad$ (1994) 1617-1620. doi:10.1271/bbb.58.1617.

32. Francisco S., Juan.J.B. N., Anunciacion.E. M., A new spectrophotometric method for quantitative multicomponent analysis resolution of mixtures of salicylic and salicylic acids, Talanta. 37 (1990) 347-351. https://doi.org/10.1016/0039-9140(90)80065-N

33. Eman S. E., Ahmed S. S., Abd Elaziz B. Abd E., A smart simple spectrophotometric method for simultaneous determination of binary mixtures, J. Pharm. Anal. 2 (2012) 382-385. doi:10.1016/j.jpha.2012.04.004.

34. Hayam.M. L., Maha. A.-M. H., Comparative study of novel spectrophotometric methods manipulating ratio spectra: An application on the pharmaceutical ternary mixture of omeprazole, tinidazole, and clarithromycin, Spectrochim. Acta - Part A Mol. Biomol. Spectrosc. 96 (2012) 259-270. doi:10.1016/j.saa.2012.04.095.

35. Nada.S. A., Nouruddin W., Hamed M.EL-F.,Osman WM, Determination of Thiomersal, Lidocaine, and Phenylephrine in their Ternary Mixture, J. Chromatogr. Sep. Tech. 04 (2013) 4-9. doi:10.4172/21577064.1000199

36. Abbas. A., Morteza B., Mean centering of ratio spectra as a new spectrophotometric method for the analysis of binary and ternary mixtures, Talanta. 66 (2005) 712720. doi:10.1016/j.talanta.2004.12.004 